\title{
Research on the Relationship between Higher Education and Regional Economy
}

\author{
Bingran Wang ${ }^{1}$ Zhenguang Wang $^{2}$ \\ ${ }^{1}$ Personnel Division of Handan Polytechnic College, Han Dan \\ ${ }^{2}$ Department of Economics of Handan Polytechnic College, Han Dan
}

\begin{abstract}
The economic development of a country or a region is inseparable from human capital, while higher education is an important factor to ensure that the quantity and quality of human capital, in other words, higher education provides human indemnification for the economic development. Conversely speaking, the regional economic development will also increase investment in education, thus promoting the development of higher education. Therefore, interaction relationship between education and regional economic is very strong. The paper combed between the education and regional economic relationship firstly, then analyzes on the affect to each other, and put forward the both the directions and paths to get the coordinated development of them.
\end{abstract}

Keywords: Regional Economic; Higher Education; Human Capital

\section{Introduction}

Economic development depends on the improvement of human quality in the society, while the higher education is the primary motivation to enhance the human quality. In modern economic and social the economy impact and effect on the higher education is increasingly more and more, and higher education is also increasingly becoming a key factor that restricts economic development. Therefore, it is necessary to adapt each other be- tween higher education and economic mutually. So the higher education should establish a positive and bilateral partnership with regional enterprises, rely on the local government's macro-planning and industrial structure fully to selfpositioning and self-planning, to achieve the combination of higher education and local economy, from the periphery to the center of society, to become the engine of improving economic and technological development then promote a new round development of regional economic.

\section{The regional economy provides a basis for the higher education}

\subsection{The regional economy provided material basis for higher educa- tion}

The expansion of higher education in need of financial investment, and regional economy provides strong financial support for the development of higher education. All aspects of development in universities, such as school building, laboratory building, a variety of research costs and special talents subsidies can't without financial support from the local government, and this financial support comes from local businesses mainly. Therefore, the development of regional economy provides material indemnification for higher education. 


\subsection{The growth of regional economy can constraint and guide educa- tional development}

The level of economic development not only determines the size, contents, organizations, teaching methods of higher education, but also determines the quality of the human. Fundamentally speaking, education is an activity to culture human capital, and it is an important part of improving social development, and its development is constrained by the level of economic development ultimately. The level of economic development not only determines the requirement of investment in education, but also determines the supply of investment in education. This necessarily requires the scale and pace of development of higher education to adapt the scale of economic construction and pace of development.

\subsection{Perfects structure of higher educa- tion}

With the adjustment of regional industrial structure and production technology structure, it leads to the optimization of the structure of higher education definitely. For instant, Shanghai's higher education in order to meet the needs of the construction of Shanghai international economic, financial and trade center, the universities adjust personnel training specifications, types and levels, cultivate various types of composite, exportoriented, application-oriented talents especially in export-oriented high-level professional personnel actively to meet the needs of adjustment of regional industrial structure and production technology of structural and to participate in international competition. In the discipline, professional structure, and the third industryrelated disciplines are showing a rapid growth trend, disciplines relate to the secondary industry in the development of pillar industries and high-tech industries begin to get rapid development. In Han- dan city, Hebei Province, to meet the needs of Equipment manufacturing industry in Matou Town, Hebei University of Engineering builds the Equipment manufacturing college and set up some specialties and courses that relate to the Equipment manufacturing industry. On the one hand it cultivate many huaman capital to the development of Equipment manufacturing industry in Matou Town, on the other hand it promote the adjustment of teaching structure of Hebei University of Engineering.

\section{Higher education can promote the development of regional economy}

\subsection{Higher education provides intellec- tual support for the development of regional economy}

In modern society, economic Competition increasingly depends on the talent competition. According to statistics, without considering other factors in the case, regional education competitiveness increases every $1 \%$, with the regional economy growth $0.178 \%$. From our present state of development of the regional economy, the southeast coastal provinces and cities are the most developed areas in Chinese economy, but also the most intensive universities, regions with the highest overall quality of the population. In these provinces, higher education cultivate a large number of professionals in various fields for the local enterprises, universities and research institutes provide technical support and the industrialization of higher education demonstrate its direct impacts on promoting regional economic development. On the one hand, higher education cultivate the future knowledge and information creators, to develop students ' creative quality and passion for innovation by the continues reform of education, teaching methods and teaching contents, to lay a solid foundation for students' cre- 
ative activities in the future. On the other hand, a large number higher academic experts and academics and high level of concentration of multidisciplinary teaching and research institutions gather in colleges and universities, not only cultivate high-quality innovative talents and commitment to cutting-edge science and technology major, but also offer a variety of diverse technical advices and services and application by using its human resources and science and technology advantages to organizations within the region to share information.

\subsection{Higher education provides an im- portant knowledge base and ad- vanced scientific and technologi- cal achievements for regional economic development}

For the development of society, the knowledge, technology, product and other things are the real power. The development of tools, processes, methodology and data management determines the level of production efficiency directly. Higher education not only provides intellectual support by cultivating the talents for the sustainable development of society, but also offers a variety of knowledge, technology and product to the social sustainable development directly by research activities, it is becoming the indispensable important factor to ensure the implementation of the strategy.

Universities are the important parts of the national science and technology innovation system. The development of higher education should be integrated with economic and social development closely, it is necessary to provide all kinds of talents to support the modernization, but also to provide intellectual contributions. Because colleges and universities coexist with multidisciplinary and knowledge transfer systematically, so they often have an advantage at concluding, collecting existing knowledge of human achievement and conducting basic research, a high level of college is often a treasure house of human knowledge. On the other hand, in modern society, with governments and the community colleges emphasizing social service functions, increasing emphasis on the development, transformation and extension of scientific and technological achievements in colleges and universities, a large number of colleges and universities have become the centers of social knowledge creation and dissemination of scientific and technological invention and promotion.

\section{The paths to achieve the coordinate development of higher education and regional economy}

\subsection{Recognize the economic function of higher education correctly}

The economic function of higher education reflect in stimulating economic growth, but we need to clear that role in boosting the economy of higher education is because it it provides a high-tech productivity and brings economic development with great potential, rather than relying their spending power to stimulate economic growth. An important factor that restricts the development of higher education is underfunded, and the major reason results in inadequate funding is educational resource utilization is not high, so it is imperative to introduce the market mechanism to optimize the educational use of market allocation of resources. While the nation supports for the development of higher education, it must focus on improving the economy functions of the higher education, as well to ensure the other normal functioning of higher education. Not only value the huge economic benefit of higher education, but also pay attention on its enormous social benefits. 


\subsection{To speed up the popularization of higher education.}

Since 1999, a large enrollment of college undergraduate and graduate have emerging for many years in China. Selfenrollment permission to expand, as well as the relaxation of entrance age are the performances that higher education becoming popularization. Higher Education should be a prerequisite for the development of diverse, including educational level and types diversification, patterns diversification, training objectives and specifications diversification, courses and contents diversification as well as the diversification of mass higher education quality standards in order to adapt to various levels of educational needs. Develop diverse high school and university continuing education actively, coordinate all levels of resources and play roles in colleges and universities, adult colleges and universities, radio and television universities and the role of self-examination fully, and promote community education positively, to form public resources for lifelong learning platform. Chinese universities should make use of their talents, equipment, information and other resources full, by improving the quality of teaching, taking of foreign cooperation to run schools, and seize the international education market actively, improve foreign students accounted for the proportion of the total number of students in school.

\subsection{Higher education should explore reform of talent cultivating modes actively}

The purpose of regional higher education is to serve human development and cultivate the high quality with innovative application-oriented talents for the regional economic development. Promote the reform of curriculum system, strengthening local courses, vocational courses, practical courses, strengthen students' skills, improve their employability, entrepreneurship abilities to adapt to the needs of economic and social development. Higher education shall implement a combination of research and product and study. The high educations should carry out personnel training, technology development, staff training through school-enterprise cooperation, to achieve mutual benefit and win together. Regional higher education in our higher education system to play a more important role, the state should support and encourage regional higher education teaching with features actively. Regional higher education should play to regional advantages and promote regional cooperation. Higher education community to support regional development, according to the mission and mandate of regional higher education, establish the partnerships among universities, government, business communities, form a good atmosphere that the whole society support the healthy development of higher education actively.

\section{References}

[1] Ximai, Wang. Research on the Investment and Output of Education[M]. China, Hebei Education Press, 1999

[2]Renqiu Zhu, Lingli Wang. The innovation and development of higher education in the era of globalization[J]. Fujian Normal University, 2003(01)

[3]Yong Xuan, Jingyu Zhang. The impact that education to the economy from the angle of education investment[J].Modern Education Science, $2008(08)$ 